\title{
Ideology as Blocked Mourning: Greek National Identity in Times of Economic Crisis and Austerity ${ }^{1}$
}

\author{
(Accepted for publication in Journal of Political Ideologies)
}

\author{
JASON GLYNOS \\ Department of Government, University of Essex, Wivenhoe Park, Colchester CO4 3SQ \\ SAVVAS VOUTYRAS \\ Department of Government, University of Essex, Wivenhoe Park, Colchester CO4 3SQ
}

\begin{abstract}
This paper approaches the 2010-2014 economic crisis in Greece from the perspective of loss and mourning, critically exploring what questions and insights this provokes. We argue first that the rhetoric of mainstream political and media elites has been instrumental in framing responses to the Greek economic crisis in patriotic terms, a frame subsequently adopted by groups from across the entire political spectrum, whether part of the establishment or not. We then draw on discourse theory and psychoanalysis to argue that attachments to the dominant austerity and anti-austerity responses to the crisis can be understood - at least in part - in terms of a failure (or not) to properly articulate and thus mourn the nationalist-inflected loss associated with economic dislocation. We sketch out two ideological pathways in the discourses of austerity and anti-austerity, which we designate as symptomatic of 'blocked mourning': a melancholic pathway that seeks to contain loss through self-blame; and a pathway of ressentiment that seeks to contain loss by attributing its cause to a series of 'others'. We argue that blocked mourning bears a direct relation to the ideological grip of the austerity and anti-austerity discourses, and that we can better appreciate the character and strength of their affective pull by drawing out the fantasmatic aspects of the narratives expressing Greek national and economic identity. Conversely, we argue that a critique of ideology can be understood in terms of the preconditions for mourning, whose satisfaction would make possible a less invested relation to the fantasmatic guarantees underpinning the austerity/anti-austerity narratives. In this view, a critique of ideology proceeds by bringing to light those factors that could facilitate a more open and deliberative articulation of loss, so as to transform and pluralise collective responses to the economic crisis.
\end{abstract}


It may be ruled out that immediate economic crises of themselves produce fundamental historical events; they can simply create a terrain more favourable to the dissemination of certain modes of thought, and certain ways of posing and resolving questions involving the entire subsequent development of national life. ${ }^{2}$

\section{Introduction}

The economic crisis in Greece brought about a crisis of representation from 2010 onwards very similar to what Antonio Gramsci had in mind when he talked about a "crisis of authority'. ${ }^{3}$ The economic crisis became the context of unprecedented social unrest and political instability, and of the redrawing of political frontiers. ${ }^{4}$ Out went a three decadeslong PASOK-ND bipartisan system. In came a more fractured political regime of representation, culminating in the 2015 electoral successes of SYRIZA, previously a minor left-wing coalition party. The crisis resulted in a simplification of the political space around an austerity/anti-austerity cleavage, commonly appearing in the form of a memorandum/anti-memorandum opposition. ${ }^{5}$ Some scholars have shown how the dynamics of the anti-austerity protests helped construct this cleavage, ${ }^{6}$ while others have drawn attention to the crucial role played in this process by populist logics. ${ }^{7}$

What is notable in these developments is how an oversimplified and powerful austerity/anti-austerity opposition has come to overshadow the public debate on political economy, including more complex and nuanced accounts of the causes of the crisis, as well as potential alternative social and economic visions for the future. ${ }^{8}$ This paper contributes to our understanding of how this polarisation and instability of Greek political discourse came about and how it was sustained. In line with recent literature that foregrounds the role rhetoric and nationalist narratives play in such an account, ${ }^{9}$ we show how references to patriotism and the nation, as well as references to themes from ancient and recent Greek history, emerged very quickly as key coordinates framing the crisis and its public perception. Much literature has focused on the nationalist tenor of left-wing and far right anti-austerity responses to the measures affirmed by successive promemorandum governments, ${ }^{10}$ but in this article we show that the patriotic/nationalist framing was already present in the discourse of the 'centre' - the mainstream governments and press - eventually spreading to encompass virtually the entire Greek political-discursive landscape, the left SYRIZA party inclusive.

We elucidate in particular the force of the competing patriotic justifications of austerity and anti-austerity, offering a deeper understanding of the polarised and unstable character of Greek political discourse, and of the narrowing of the political economy debate. This nationalist narrative context furnishes the background against which we identify 'loss' as a promising interpretive frame within which to organize popular interpretations and affective investments. Whether expressed explicitly or implicitly, the presence and prominence of loss provides some rationale for turning to psychoanalytic categories in critically explaining the way the public discourse of the crisis developed from 2010 onwards. The category of mourning, in particular, is central to our account because we discern two main modes of attachment to the nationalist narratives with which austerity and anti-austerity have been articulated. In this view, these two modes - what we call melancholia and ressentiment - can be understood in terms of a failure to process loss properly, in other words, a failure to mourn.

What is interesting about this failure to process loss properly is not simply that it can be 
glossed as a case of 'blocked mourning'; it also bears a direct relation to the ideological grip of such discourses. We argue that we can better appreciate the character and strength of this ideological grip by drawing out the fantasmatic aspects of the narratives animating Greek national identity, and by showing how these features tell us something about the loss at stake. Conversely, we argue that a critique of ideology can be understood in terms of the category of, and conditions for, mourning. Mourning entails meeting fundamental, fantasmatic selfimages with the judgement that they are no longer, thereby opening up a new pathway toward a future yet to be decided and only guaranteed through collective judgement. We use this framework to argue that elite political discourse and practice has served to reinforce popular attachment to Greek nationalist fantasies that lend ideological support to austerity and anti-austerity measures, and in this way they contributed decisively to the production of a highly polarised and volatile political order. As a result, the discursive conditions for mourning the loss wrought by economic dislocation were not satisfied, making alternative visions of Greek national and economic life harder to discern and promote.

\section{Discourse theory and psychoanalysis}

We develop a distinctive approach to the analysis of the Greek crisis drawing on political discourse theory and psychoanalysis. ${ }^{11}$ We draw attention here to two importrant features of such an approach: the practice of articulation; and the role psychoanalytic concepts can play, in particular fantasy and mourning. The practice of articulation simply foregrounds the nonnecessary character of the relation between elements, for example, between economy and nation. This captures the way such terms link up with one another through concrete practices of 'articulation' that depend on a complex mix of context and intention which is hard to predict or anticipate. Consider, as an example, how the pro-austerity/anti-austerity opposition is often used interchangeably with the pro-memorandum/anti-memorandum opposition, or the pro-/anti-Europe one (in the discourse of pro-austerity parties). This observation raises a question about whether such interchangeability might conceal interesting complexities and nuance. After all, it is perfectly straightforward to imagine anti-memorandum advocates opposed to the specific memorandum proposals, but still broadly in favour of austerity measures. ${ }^{12}$

Viewing discourse in terms of a practice of articulation means treating the relationship between discursive elements as non-necessary. This trains our attention on the 'articulatory links' being made between such key elements as 'austerity', 'nationalism', as well as different actors and groups from across the political spectrum. However, although there is no necessary relation between these elements, it is worth noting that there is an obvious asymmetry in the Greek case: all want to portray themselves as patriotic, whatever their position is on the memorandum, austerity, or the mainstream 'establishment'.

Moving now to the second key feature of our approach, we argue that a turn to the psychoanalytic categories of fantasy and mourning can contribute analytically and critically to an account of the polarised and volatile character of Greek crisis discourse. The significance of psychoanalysis for a theory of ideology, the category of fantasy in particular, has been highlighted by many scholars, often in the pages of this journal. ${ }^{13}$ We do not propose to rehearse these arguments here. Suffice to say that the fantasmatic - and ideological - dimension of political discourse is understood to be linked to those aspects of a narrative to which subjects become overinvested as a way of coming to terms with an ultimately precarious and unstable existence. This is the significance of fantasy in relation to articulation: the fantasmatic narrative conceals the non-necessary character of articulation. 
As to the category of fantasy, this can be understood in terms of its content: 'its ideals, the obstacles to achieving such ideals, the way challenges can be overcome, the vision of a successful outcome, and the imagined consequences of failure'. ${ }^{14}$ And this means that different fantasmatic narratives promote, support and justify different normative visions and render different sets of norms and practices possible. However, apart from the normative dimension evident at the level of content, fantasy incorporates an ideological dimension linked to the subject's mode of attachment to this content. ${ }^{15}$ The specificity of fantasy compared to other forms of discursive formation is that it serves also as a device to protect the subject from anxiety. This anxiety is associated with the contingency of social relations, which the subject seeks to avoid through affective investments in imaginary and symbolic guarantees underpinning the norms of a practice (figures, objects, ideals, etc.). The ideological dimension of fantasy is thus linked to the role it often plays in pre-empting the contestation of norms, in this case austerity or anti-austerity norms, and possible detachment from them. It follows that the task of the 'critique of ideology' is an ethical task precisely because it constitutes an attempt to render these attachments visible despite the anxiety such a process might provoke.

This distinction between the ethical and the ideological dimensions of fantasy is captured in a range of ways in psychoanalytic theory. ${ }^{16}$ There are already a range of concepts invoked in relation to the Greek economic crisis that could be said to point to an affinity with this perspective, including 'de-pathologization', 'avoiding idealisation', and 'de-exoticization', ${ }^{17}$ resisting 'press stereotyping', 18 'moral narrativisation' ${ }^{19}$ and 'the culturalization' of the crisis. ${ }^{20}$ Here, however, we place mourning and blocked mourning at the centre of our interpretive frame, using this to organize popular expressions and affective investments in nationalist narrative responses to the economic crisis in Greece. ${ }^{21}$ What makes this vocabulary appropriate to a crisis situation is that mourning (and blocked mourning) describes not simply a response to an experience of loss; crucially, it also describes the process of exploring loss. It is about exploring what the experience of loss says about what exactly is lost and the manner in which we can engage in such a process of exploration. When viewed in this way, we can understand the many expressions of dislocation as so many expressions of loss, actual and potential: loss of employment, loss of financial security, loss of socio-economic prosperity, loss of a 'growth' economy, loss of national sovereignty, loss of hope, loss of a particular self-image and identity, loss of national pride, loss of dignity. But from a psychoanalytic perspective, what we feel is lost is often something in which we are fantasmatically invested. This experience of loss is crucial, since different ways of discovering, constructing, and coping with loss can reveal or conceal possibilities of transformation. ${ }^{22}$ Following Lacan, we could say that mourning, as an ethical response, would signal a transformation in modality from 'desire for recognition' (characterised by containing and reifying loss) to 'recognition of desire' (characterised by opening up loss to a process of exploration). Recourse to loss and mourning thus offers us a way to critically understand the affective reactions to the economic crisis, austerity in particular.

\section{Research Strategy \& Methodology}

In what follows, we demonstrate the way the economic crisis, and the austerity/anti-austerity responses more specifically, have been articulated in a strikingly nationalist-patriotic manner, paying close attention to its genealogical origins in the mainstream governmental and media discourses. Looked at more closely, however, we find two distinct 'articulatory pathways' animating the responses to the crisis - the melancholic and ressentiment pathways - both of 
which can be understood in terms of 'blocked mourning', but which are distributed unevenly across the political spectrum. By training our focus on the question of loss, we discover a romantic fantasmatic trait that appears to underlie both pathways, and we claim that a critique of ideology ('crossing the fantasy') can proceed by revealing and opening up to transformation this common feature.

In making this argument we draw on a corpus that covers the period from 2010 to 2013 , comprising discourses derived largely from government and newspaper sources, but we also make reference to the discourse of the left party SYRIZA during this period in order to demonstrate how the discourse of patriotism became rather totalising in its scope and reach across Greece's political landscape. Methodologically, we focus on six key periods in which Parliament was voting on austerity measures, or in which national elections were taking place. These are: the vote on the first Memorandum of Understanding between Greece and the Troika (7 May 2010), the vote on the mid-term plan of 2011 (29 June 2011), the vote on the second Memorandum (12 February 2012), the vote on the multi-bill of 2012 ( 7 November 2012), the votes on the two multi-bills of 2013 (28 April 2013 and 17 July 2013), as well as the two national elections of 2012 (6 May and 17 June). ${ }^{23}$ The newspapers from which we collected material were the four newspapers with the highest circulation at the beginning of the crisis, representing key positions from the left to the right of the political spectrum. In order of circulation (starting from the highest), these are: Ta Nea (centre, traditionally associated with PASOK), Kathimerini (centre right, traditionally associated with the Nea Demokratia party), Ethnos (centre), and Eleftherotypia (left-wing - at times associated with the left-wing section of PASOK). To this selection we also added Avgi (left wing, associated with SYRIZA). While Kathimerini and Ta Nea expressed clear overall support for the austerity agenda, Eleftherotypia and Avgi expressed overall condemnation. Commentaries in Ethnos were more mixed: some strongly condemned the austerity measures, and some, while opposing them, also saw them as unavoidable. We read the newspaper editions of the week before the vote and also on the day of the vote, to see how these newspapers framed the austerity reforms being voted on. We drew on Prime Ministers' speeches too. Sections of the latter were reproduced in the media, but we were also able to examine them in their entirety, as they were uploaded on the official webpage of the Prime Minister of Greece. ${ }^{24}$

Our newspaper databases comprised all political commentary columns of the aforementioned newspapers. The texts were then subjected to qualitative interpretation involving deep immersion in, and reflection on, the corpus in order to gain a settled picture of the content and tenor of the narratives produced during the austerity/anti-austerity discussions and debates. The vast majority of the extracts we use to support our interpretations come from these databases, but we supplement them occasionally with quotations from texts derived from government sources and from newspapers printed outside this period, particularly when they are better able to capture the storylines identified in our original database.

In interpreting this material, it is important to keep in mind that Greece had three different pro-austerity governments during this period: (a) the social-democratic PASOK government with Georgios Papandreou serving as the Prime Minister (2009-11); (b) the government led by technocrat Lucas Papademos and supported by PASOK, the conservative Nea Demokratia, and the extreme right LA.O.S. (2011-12); (c) the government led by Antonis Samaras and supported by Nea Demokratia, PASOK, and, for a certain period, DIMAR (2012-2014). In terms of the broader political context, the Communist Party, the main traditional left-wing force that had secured third place in most elections since the early $1980 \mathrm{~s}$, lost considerable support: since the 2012 elections, Golden Dawn, a previously marginal neo- 
Nazi party, gained support to secure third place (a position they have maintained since). Within the space of a few short years, SYRIZA, a small left-wing anti-austerity party gained popularity during the crisis period and eventually became the main party in government following the national elections of 2015 (sharing power with the ultra-conservative rightwing anti-austerity party ANEL).

\section{Nationalism as an all-encompassing horizon}

It is worth pointing out at the outset that much academic work identifies the rise of nationalist discourse during the period under investigation exclusively with anti-austerity responses to the crisis; ${ }^{25}$ and this echoes earlier arguments that link nationalism with the "political extremes' in Greece. ${ }^{26}$ There is, of course, a fully justified and well-documented academic interest in the rise of the far right in response to the Greek economic crisis. ${ }^{27}$ Such analyses of nationalist rhetoric, however, often miss the intense mobilisation of patriotic discourse by the 'moderate' centre, in other words, the pro-austerity governments of the crisis period.

The proliferation of references to nationalist themes in official pronouncements and mainstream media is something that have recently been explored by discourse-analytical approaches, some operating on a micro level, ${ }^{28}$ and some on a macro level. ${ }^{29}$ These works demonstrate how national identity and memory was politicised and became an important part of the conflicting discourses in the context of the crisis. Our current research supports these findings, and attempts to explain the emergence of this kind of conflict, pointing to the dynamics that can account for its force.

In what follows we draw on our empirical material to show how the nationalist inflection was articulated by the moderate centre of the Greek political establishment. This is important not just because it offers a more nuanced alternative to the usual identification of nationalist rhetoric with the extreme right, but also because it helps us better appreciate the 'centre's' genealogical role in politicizing national identity themes vis-a-vis the economic crisis and the austerity agenda. In fact, the political centre defined early on the terrain of debate in terms of patriotism. The nationalist-patriotic narrative came to undergird not just the austerity position of the centre, but also the anti-austerity positions of the right and the left, including SYRIZA. This was a significant shift in Greek political discourse and the discourse of the Left in particular, especially if one takes into account the historical association of Greek nationalist discourse with the right and its role in supporting the persecution of and violence against the left for almost half of the $20^{\text {th }}$ century. ${ }^{30}$

However, the genealogical role of the moderate pro-austerity government and press can be understood not only as a way of underlining how the nationalist framing process is more complicated than has often appeared in previous discussions that associate nationalism almost exclusively with anti-austerity discourse. Its genealogical significance can also be appreciated by noting how the nationalist frame was not the only (or necessary) frame with which to inflect the austerity/anti-austerity discussion and debate in the first place. Other frames were possible and were more visibly present in earlier stages of the crisis: economic-technocratic frames were possible, as were neoclassical or Keynesian ones, which were largely subsumed by the pro-/anti-memorandum frame. The real possibility of alternative framings can also be appreciated through a comparative exercise, by looking at the shape of the austerity/antiausterity debate in other countries. Comparisons with Spain and Ireland have shown that the implementation of austerity reforms in these two countries did not result in a nationalist inflection of political discourse to the same degree. ${ }^{31}$ And comparisons with Portugal have 
shown that dissatisfaction expressed in that country was locatable almost exclusively on the left-right economic axis, and mostly projected towards the EU, while in Greece it was also expressed on a left-right cultural axis and directed towards the national political system. ${ }^{32}$

Turning again more directly to the case of the Greek economic crisis, the role of the moderate centre in propagating the rhetoric and narrative cannot be overstated. From George Papandreou's 'road back to Ithaca' speech of 2010, through the speeches of Lucas Papademos's tenure, to even sharper expressions in the political discourse of Antonis Samaras, all three pro-memorandum governments of the period used this patriotic frame forcefully to inflect the austerity response to the crisis.

It was in the discourse of the Prime Minister George Papandreou that the theme and signifier 'patriotism' appeared for the first time in an attempt to present the crisis as an evil that can only be defeated by a united Greece. In using the term 'patriotic duty' Papandreou transformed it into one of the main signifiers in the discourse of the pro-austerity camp. Traces of this logic can be found in his announcement that the Greek state would resort to the European Financial Stability Facility mechanism to help 'Greece get back on its feet and make Greeks feel proud'. He described this decision as the beginning of a new 'Odyssey for Hellenism'. Famously, Odysseus lost his way on his return home to Ithaca following the Trojan War. Papandreou, however, asserts that

this time we know our way back to Ithaca and we have charted the waters... [W]ith a new collective consciousness and common effort we will get there safely, more certain, more just and proud. Our final goal, our final destination, is to liberate Greece from surveillance and patronage, to liberate the forces of Hellenism, to liberate every Greek man and woman from beliefs, practices and systems that have been obstructing him in everything for decades. [...] Our inspiration, our belief, lies in this very country $[\ldots]$, this wonderful people....

Despite the sobriquet 'technocrat' applied to the leader of the subsequent coalition government, Lucas Papademos also drew extensively from the patriotic repertoire in attempting to persuade people of the necessity of austerity measures, and we shall refer to some relevant extracts later in the paper. For now, we focus on the discourse of Antonis Samaras two years on, where we find even stronger nationalist references. We find him invoking a temporal narrative in which a glorious past has been interrupted by the crisis. This crisis and the sacrifices we are called on to make through the proposed austerity measures are presented as a temporary phase that we have to endure in order to reach a 'loopy' future that involves returning to a trajectory which belongs simultaneously to Greece's past and future destiny, identified with Hellenic glory. Samaras's vision is thus a 'restorative vision' that seeks to restore continuity with an earlier era of economic prosperity, over-determined by the glory of an even earlier Hellenic past. This was evident in Nea Demokratia's campaigns for the elections of May and June 2012 and was heightened in Samara's discourse as Prime Minister. One of the most characteristic examples of an articulatory practice that reinforced this inmixing of economic and nationalist elements is a series of videos screened on television and on Nea Demokratia's YouTube channel, titled 'The Strength of a Nation', where Samaras expresses a desire to:

unite the forces of all Greeks. I have suggested a plan, but also a vision... Above all, I ask you to believe in yourselves, in Greece's wealth, in the inexhaustible source residing in every Greek. The plan we are suggesting can lead the country to 
tomorrow. The vision we are suggesting can unite Greeks. And when Greeks unite and acquire faith in themselves they can do wonders. ${ }^{34}$

A few seconds later, we find Samaras screaming: 'Give me the strength of a nation so that we can win the battle of our fatherland', while images appear depicting famous Greek monuments and historical figures, reinforcing a powerful national narrative that stretches from antiquity to the present: Aristotle, Maria Callas, heroes of Greek Independence, Pericles, Alexander the Great, Hagia Sofia in Istanbul (symbol of the Byzantine period and Greek irredentism), the Olympic torch relay ceremony in Olympia. In the last shot Samaras himself appears as the next step in this compelling trajectory, thereby also standing as candidate-instrument of this ineluctable historical unfolding. Another video presents similar images of sacred monuments and figures described as 'looking through your [the voter's] eyes', hoping not to be let down. Samaras explains: '[w] hen things become difficult, a people have to look back to the past. And when they can see such a great history, they can look ahead with courage and determination... I have deep faith in Greek strength,[...] in the Greek's love for the fatherland... Give me the strength of a nation, to show the whole world what Greece means, what dignity means, what a strong soul means'. ${ }^{35}$ These sentiments and narratives also informed much of Samaras's public speeches in asking for support for the continuation of the austerity agenda.

We have focused primarily on the pro-austerity 'moderate' centre so far because its discourse has served to define the terrain of debate, subsequently taken up and reinforced by a range of other actors, particularly on the right of the political spectrum. There is, however, an equally potent nationalism to be found in the anti-austerity messages uttered by groups on the left, including SYRIZA. In fact, SYRIZA spokespersons did not in the end hesitate to adopt nationalist rhetoric, often identifying their political opponents as unpatriotic traitors. For example, SYRIZA MP and (and later minister), Dimitris Stratoulis, opposed the multi-bill of November 2011, stating that "not even the [...] Nazi collaborators ever dared to introduce such measures with respect to labour relations'. The leader of SYRIZA, Tsipras himself, often presented the pro-austerity governments as puppet governments, construing them as agents spearheading an invasion of Greece. In his words, the dilemma of the 2014 elections was not 'Samaras or Tsipras', but 'Greece or Merkel'.

\section{Symptomatic patterns of Blocked Mourning: When talk of the cause of loss short- circuits talk about loss}

The crisis consists precisely in the fact that the old is dying and the new cannot be born; in this interregnum a great variety of morbid symptoms appear... ${ }^{37}$

The totalising character of nationalist rhetoric during the Greek crisis period, as demonstrated above, is certainly striking. But it is important to note that this unity of rhetoric belies important differences of emphasis that can help us better understand the force underpinning the austerity and anti-austerity discourses. Looked at more closely through a psychoanalytically-informed interpretive frame that foregrounds the idea of loss, we can discern in the nationalist narrative two distinct modes of subjectivity at play: melancholia and ressentiment. We argue that both modalities comprise pathways of 'blocked mourning' because they serve to quickly define or contain loss in a way that closes down the process of discovery and deliberation about loss and thus the possibility of seriously contemplating alternative social and economic visions. Moreover, as we will see, the two pathways are 
distributed unevenly across the poles of the austerity/anti-austerity opposition. While the nationalist-melancholic path appears to be articulated in a way that almost exclusively supports the austerity position, the path of ressentiment can be readily found in the rhetoric of both austerity and anti-austerity advocates.

\section{The Melancholic Way}

The austerity governments pre-empted the process of discovery and deliberation about loss first through the quasi-melancholic rhetoric of self-blame. In his psychoanalytic reading of the European justifications of austerity, Stavrakakis has noted 'a process of creating and sustaining shame and guilt and thus legitimising punishment (in the form of radical impoverishment, sky-rocketing unemployment, liquidation of labour and other social rights) ${ }^{38}$ But similar strategies of justification were put at the service of the austerity reforms within Greece. In provoking affective responses of self-reproach and moral culpability, such strategies promote acceptance of the austerity measures, presenting the reforms as fair 'selfpunishment'. In the words of Theodoros Pangalos, then deputy prime minister, responding to protesters outside parliament in 2010, '[w]e all gorged on it [the money] together' ${ }^{39}$ This way, Greeks themselves are cast as responsible for the loss of prosperity and they should thus atone for their own errors by accepting austerity as due punishment.

In a crucial speech addressed to Parliament before the vote on an important aspect of the austerity/bailout package, George Papandreou amplified this sentiment by insisting that what has to be opposed is not the austerity measures, but our resistance to moral catharsis, locating the cause of the current predicament in ourselves: 'The enemy is within us, the barbarian is inside the walls'. We need to engage in a 'battle against ourselves': '[W] ho is the real enemy? Who spins the spider web that keeps us dependent?' For Papandreou the answer is we ourselves: 'our parasitical economy' that depends on foreign products instead of producing Greek ones, relying on subsidies and allowances from the EU that give no incentive to improve a poor and inefficient education system; our dysfunctional welfare state that feeds dependence and our clientelist state which fosters an anti-meritocratic climate that promotes easy 'jobs in the public sector'. Addressing the MPs, Papandreou stated: '[A]11 of us here should carry the burden of our responsibility and support the [bailout] agreement'. Why do all MPs have this 'historical responsibility'? Because, all political forces have contributed to the situation that the country is facing today: 'It is our fault either because we did it, because we tolerated it, or because we closed our eyes to it. Yes, it is our fault. Every appointment that we did as a favour, every loophole that we created, every privilege that we legislated, every union that we defended, every unreasonable demand that we helped to realise, every fake promise that we gave, every trade unionist that we nurtured and who then misunderstood his role'. 'Our fatherland demands from us that we move beyond ourselves'. ${ }^{40}$ Guilt and shame is thus produced and applied liberally across the entire political spectrum and population. Within such a morally-inflected narrative opponents to austerity are not honestly owning up to the irresponsibility of their past. Although initially this call to affirm and accept responsibility and austerity was accompanied by a promise of hope and the exploration of new ways of putting Greeks on the path of progress (a return to Ithaca), the new waves of austerity measures quickly shifted away from this open and potentially more positive vision toward justifications pitched in the shrill tones of TINA (there-is-noalternative). ${ }^{41}$

Mainstream Greek media quickly picked up this theme, fostering and reinforcing a melancholic climate of guilt and shame. It systematically promoted an affective discourse of 
loss that strongly and simultaneously emphasised patriotism and self-blame, drawing on biological metaphors:

We are a country that is experiencing the end of a period of prosperity that went hand in hand with a decline in leadership, values, and institutions. We forgot what 'I love my fatherland' means because we got entangled in a vicious circle pursuing indulgence, comfort, mindless bliss... We need to watch out not to ever allow this crisis to develop into some kind of national defeat... At this point, in the wake of our gene of self-destruction becoming dominant, one can only raise one's hand and cross oneself, hoping to avoid the worst from happening.... 42

This 'gene of self-destruction' appears as a metaphor for many things, particularly for those of a leftist ilk, and certainly as a warning against any opposition to austerity measures. But the theme of actual and potential loss through self-destruction was expressed in other ways. Some media commentators, for example, have identified the 'oriental' aspect of Greek identity as responsible for the crisis and for Greece's resistance to full 'Europeanization':

Greece may have acquired pro-European parties, but it did not acquire European parties. [...] [I]t was governed by parties with European orientation ... but through oriental practices. The institution of the clientalist state and of parasitism, the complete contempt for meritocracy, the political bazaars with selfish motives but cataclysmic consequences for the country, the medieval demands of guilds became the very identity of these parties and brought us to where we are today. ${ }^{43}$

Beyond the statements found in Papandreou's speeches and much mainstream media the discourse of guilt and moral catharsis would be taken up too by the government of technocrat Lucas Papademos, which argued that the loss of economic and social security should not be used as a way to avoid taking 'responsibility'. ${ }^{44}$ On the contrary, as Sevastakis notes, 'sacrificial language is... summoned in order to provide legitimacy to very specific "rational reforms", establishing a 'public morality of sacrifice' that was to help usher in a neoconservative shift in the discourse of the elites. ${ }^{45}$ In the words of Papademos: 'We will not get out of the crisis without sacrifices. We are a proud and duteous [philotimos] people. We know what struggles mean. And this today is the struggle for our fatherland'. ${ }^{46}$ This discourse thereby demands personal sacrifices for the sake of national survival, understood in traditional, almost romantic terms: 'we are [not in the custody of the troika, but] in the custody of History'. ${ }^{77}$

\section{The Way of Ressentiment}

The above account illustrates the melancholic way of containing loss. In this view, Greek economic woes are understood in relatively short order to be the product of moral corruption, for which sacrificial moral catharsis is the solution. Self-blame is invoked to stoke up the kind of guilt and shame that can serve as emotional support for calls to self-punishment, thereby tightening the ideological grip of the austerity measures. In this melancholic context loss cannot be processed in a way that can give rise to alternative visions of a nationaleconomic ilk. This is because talk about the cause of loss (moral corruption) has shortcircuited discussion and deliberation about the character of this loss: about the content of this loss, about what this loss means to us, and about what it could mean to us.

But there is another prominent way in which loss is contained. Instead of attributing the cause of (temporary) loss to our decadent, morally depraved selves, we attribute it instead to others; 
and there are a variety of figures that appear to occupy this position. If melancholic selfblame was about individual and complicit guilt, and the acceptance of austerity as deserved self-punishment, ressentiment renders specific groups other than ourselves responsible for loss and its consequences. Here we suggest that the tendency to affectively invest in scapegoat figures as a way of containing loss can be critically approached through the Nietzschean concept of ressentiment. Ressentiment could be read from a psychoanalytic point of view as a particular mode of organising enjoyment. Fantasies of victimhood and revenge, for example, often appear in the mode of 'theft of enjoyment', ${ }^{48}$ wherein our enjoyment is experienced as 'stolen' by others. Such a reading is not entirely at odds with Nietzsche's formulation, and indeed appears to stress a dimension already implicit in his own work, for example, when he observes how subjects gripped by ressentiment 'enjoy being mistrustful and dwelling on nasty deeds and imaginary slights', or tend to blame others for their suffering:

[E]very sufferer instinctively seeks a cause for his suffering; more exactly, an agent; still more specifically, a guilty agent who is susceptible to suffering - in short, some living thing upon which he can, on some pretext or other, vent his affects, actually or in effigy. ${ }^{49}$

Ressentiment can thus be understood as another pathway of 'blocked mourning' that signals a type of response to, or containment of, loss. For William Connolly, ressentiment is associated with a refusal to acknowledge that we are attached to fantasies of omnipotence and fullness, so that when these fail to materialise, we are more than ready to project the cause of this failure onto others: 'those who resent the fragility of their own fundamentals are apt to blame some other group or doctrine for this obdurate condition' ${ }^{50}$ In that sense, ressentiment should be distinguished from resentment, although the two can be linked. No doubt ' $[\mathrm{i}] \mathrm{t}$ is unlikely that a new social movement could unfold without its potential members feeling resentment toward key elements in the status quo, ${ }^{51}$ Resentment may thus be understood as a necessary condition for politics, for the contestation of norms and practices, and the production of political frontiers. Ressentiment, though, is different, in the sense that it functions at an existential level. While resentment produces political opponents, ressentiment produces existential threats and enemies. It is, indeed, possible that accumulated and disregarded social resentments may slide into ressentiment:

Politics underscores the extent to which as mortals we are always, already subject to painful limits and losses. Indeed, the fact that in the political domain individuals and collectives can suffer irreparable harms illustrates how political conditions and events directly tap into fundamental insecurities and reinforce the sense of impotence that underpins ontological ressentiment. ${ }^{52}$

At this point it is worth highlighting that, unlike the case of melancholia which was dominant in the government's pro-austerity political discourse and mainstream media, the ethos of ressentiment has cut across the entire political spectrum, finding itself expressed in both proand anti-austerity responses to the crisis in and outside the 'establishment'.

Since, as we will explain shortly, the conditions for mourning were absent, the eruption of ressentiment was not unexpected as a prominent alternative to the melancholic containment of loss. Take the grassroots mobilisations of Aganaktismenoi (2011), for example. Although these mobilisations were characterised by demands for more democracy, and for attentiveness to popular grievances, sections of the movements also exhibited features of ressentiment, 
demanding violent revenge that targeted the political and media establishment as a whole. As Theodossopoulos's anthropological analysis has showed, anti-austerity protests showed a great degree of ambivalence, resisting austerity measures, but largely in ways that reinforced the hegemony of nationalist discourses. ${ }^{53}$

Even left-wing media discourse appeared split between trying to present and defend alternative ways of confronting the crisis on the one hand, and resorting to nationalist blaming on the other. Eleftherotypia's cartoons often depicted German politicians as Nazis, and the pro-austerity Greek governments as Nazi collaborators, a heavily charged figure from the times of the Nazi occupation of Greece. Some SYRIZA representatives also resorted to similar sorts of comparisons and to national otherings. ${ }^{54}$ Alexis Tsipras, in an attack against the coalition government led by Papademos, said: '[S]ome Greeks are not so Greek after all. Those who govern us'. ${ }^{55}$ A few months later, before the 2012 national elections, he emphasised that PASOK and New Democracy 'looted Greece and then they lowered the flag and handed it to Merkel'. ${ }^{56}$ Although by no means characteristic of the majority of its commentators, similar language also started featuring in SYRIZA's newspaper Avgi around the same time. This was also expressed in Avgi's political cartoons. For example, Papademos was depicted crushing ancient Greek statues under a machine press, while supporters of the memorandum were presented as equivalent to Nazi collaborators and supporters of the 19671974 dictatorship. ${ }^{57}$

Pro-austerity governments, in turn, accused the anti-austerity opposition for being antipatriotic and anti-Greek. This rhetoric reached its peak during the Samaras tenure after it became evident that SYRIZA's popularity was increasing rapidly. In a revival of old rightwing anti-communist discourse, Samaras claimed that the left 'would not mind seeing Greece getting destroyed', and that those who do not have faith in the results promised by austerity are basically 'undermining the country', discouraging foreigners from investing in Greece, and contributing actively to the production of unemployment.

I do not know if they [SYRIZA] dislike this country. Sometimes I think that they might even hate this country! ... They want to deprive Greeks of what? Of the Hope that is coming. They want them to be what? They want them to be desperate and on their knees. We insist on wanting them standing upright and proud! $!^{58}$

But ressentiment extends beyond the exchange of accusatory insults between political parties. On certain occasions, pro-austerity governments constructed specific social groups as culprits for economic hardships. For example, public workers have been portrayed as responsible for the recession, particularly the injuries inflicted on the private sector: the closure of businesses and the subsequent loss of jobs, as well as the massive collapse of the low-middle class. As PASOK MP and health Minister, Andreas Loverdos, succinctly put it, ' 1 million [public sector] workers harass 10 million citizens,. ${ }^{59}$ Weak and marginalised social groups, like immigrants, also became a target in this strategy. Amid severe cuts in health care, Loverdos had also depicted immigrant women sex workers as the culprits for the alleged increase in the spread of certain diseases, contaminating the nation. As he said, 'the infection passes from the undocumented migrant women to the Greek male customer, into the Greek family'. ${ }^{60}$ The pro-austerity camp can thus be understood as attempting to deflect indignation away from the austerity agenda, redirecting the affects of loss onto others. A characteristic example of such redirection of anger through scapegoating is Minister of Finance Evangelos Venizelos's response to the accusations of delaying the investigation of a list of Greeks suspected of smuggling large amounts of untaxed money to banks outside Greece. When it became known 
that there was such a list and that the government had not taken the expected investigative steps, but had instead tried to bury the case, this became the cause of angry reactions accusing the government of concealing corruption. When Venizelos was asked if he could remember any names from the list, he said that he could only remember that the names at the top of the list were Jewish. ${ }^{61}$ Samaras was even more persistent in the targeting of immigrants, blaming them for welfare state insufficiencies, like the lack of nurseries: 'nursery schools are full of immigrants and there are no places left for Greeks in kindergartens'. ${ }^{62}$ The cause of unemployment - one of the most severe consequences of austerity according to many commentators - was also attributed to immigrants by means of spurious correlations: 'We have as many illegal immigrants as we have unemployed' ${ }^{63}$ The Minister of the Protection of the Citizen argued that immigration is the big threat to the nation, not the economic crisis, promising harsher measures targeting immigrants:

The country is perishing. Since the Dorian Invasion 4,000 years ago the country has not experienced a large-scale invasion like the one today. [...] It constitutes a bomb exploding the foundations of our society and state. [...] A solution to [the problem of] migration is a great national challenge. We are about to collapse. [...] We are facing the danger of complete social erosion. Migration may be a problem greater than the economic one. ${ }^{64}$

In closing this section we should note how other actors beyond mainstream governments and media also sought to capitalise on the popular resentments and frustrations in similar ways. The most extreme example of nationalist ressentiment comes, of course, from the Neo-Nazi Golden Dawn, a party whose aggressive rhetoric has found support among a sizeable part of the electorate due to its promises to exact revenge not only against the mainstream political and media establishment but also against immigrants. ${ }^{65}$

\section{Ideology as Blocked Mourning: When the Conditions of Mourning are Unmet}

In adopting and applying loss as an analytical grid to the empirical material within a broad discourse theoretical framework, we have pointed not simply to the significant role that the content of a patriotic frame plays in constituting/shaping the character of the austerity/antiausterity debate. We have also drawn attention to the subject's mode of attachment to this content through distinct processes of 'blocked mourning'. Our findings receive some independent empirical support from the work of Lialiouti and Bithymitris, who demonstrate that the pro- and anti-Memorandum camps have mobilised national identity in distinct ways. ${ }^{66}$ They argue that while the pro-memorandum camp often deploys a 'self-blaming' interpretive scheme, where Greece is responsible for its economic failures, the antimemorandum camp is more likely to resort to variants of a 'victimisation' scheme, where Greeks are threatened by an external enemy. While these theses share a deep affinity with our own findings, the theoretical-analytical grid we bring to bear on the material gives these findings a very particular twist. It suggests that these two pathways are symptomatic of something linked to loss. The rush to blame a morally-depraved self or to blame threatening others serves as a way to avoid talk about loss. A swift move to reify the cause of loss deflects attention away from an exploration of loss itself. Our approach suggests that focussing on loss and mourning prompts a series of more pointed questions, leading us for one to be more specific about what exactly the objects of loss are or can be, and therefore to be more precise about the fantasmatic stakes of the nationalist narrative. 
As we have noted in earlier parts of this paper, affectively invested elements linked to loss can serve as pointers to the fantasmatic stakes of nationalist narratives, and arguably the most potent and affectively invested expression of loss has been made in terms of pride and dignity. This is evident in the quotes we have cited above, where the restoration of pride is presented as one of the promises of the implementation of austerity. But this is a theme that also featured strongly in Alexis Tsipras's opposition to austerity. The peak of the reference to dignity was reached in his announcement of the referendum of July 2015 in the Greek Parliament, where the restoration of dignity was repeatedly highlighted as what was at stake. $^{67}$

From a psychoanalytic point of view we can say that affectively potent reactions are typically revealed when the subject's unconscious fantasy is exposed and threatened in moments of dislocation. Imaginary and symbolic supports wobble and the subject glimpses the anxietyprovoking radical contingency visible just below the surface of fantasy. However, since these supports are to a great extent unconscious, what has been lost is not directly or immediately apprehensible. ${ }^{68}$ Therefore the subject needs to go through the difficult process of recognizing, and actually constructing this lost object, ascertaining its significance, and eventually withdrawing affective investment from it in order to consider re-investing elsewhere. This is the process of mourning.

However, it is not at all self-evident that a dislocatory experience will be followed by mourning. It is important to emphasize that mourning is a very demanding task, since it requires from the subject to admit that a part of its security is gone. Furthermore, since the loss and its object(s) are not directly accessible, but have to be articulated as such, mourning is also an open-ended process with no single possible outcome that can be pre-determined. ${ }^{69}$ Thus, it puts subjects in a state of ambivalence, something noted in anthropological accounts of how individuals have coped with the loss of security during the crisis. ${ }^{70}$ Our point here is that mourning is only one of several ways to cope with loss; in fact it is more likely that we will cope with loss in other ways that seek to preserve the fantasmatic investment with which we are familiar. Hence the idea of 'blocked mourning'. In contrast, mourning establishes a different, less invested relation to the fantasmatic supports of our identifications, making evident in this way the ethical significance of mourning and its conditions of possibility. ${ }^{71}$ In the case of the Greek economic crisis, mourning could signal the loosening of an overinvested affective attachment to a particular (national) fantasy.

Given the prominence attributed to the loss of pride and dignity in public political discourse, perhaps we can qualify it as a 'master' loss, overdetermining the many other losses expressed in the media and in the streets. In this view any one of a series of concrete losses (loss of income, security, way of life, economic growth, hope), become highly charged or invested insofar as they come to embody a (threatened) loss of pride and dignity. But what fantasmatic narrative underlies this potential loss of pride and dignity?

Perhaps one of the strongest fantasmatic narratives of the political discourse on the crisis has to do with the threatened collapse of a potent national self-image built around the inextricable link between Greek identity and Europe as an ideal. As scholars of Greek nationalism like Stathis Gourgouris have demonstrated, this sense of identity is fundamental and is based on modern Europe's discovery of its own origins in ancient Greece. ${ }^{72}$ This does not simply constitute a beatific image, but also a normative ideal that needs to be performed and satisfied. ${ }^{73}$ De-orientalising, modernising, and catching up with the West, have been justified in modern Greek history in terms of fulfilling Greek destiny as the cradle of Europe and 
Western civilisation more generally. Politically, this image has served to normalise the modernisation thesis, furnishing it with ideological support. In an earlier echo of this idea in 1977, then Prime Minister Konstantinos Karamanlis countered those questioning his support of Greece's accession to the EU by simply claiming that: 'We belong to the West'. ${ }^{74}$

The importance of the figure of the West for Greece as a normative ideal has been emphasised not only in different accounts of Greek national identity, but also in academic accounts of Greek political culture. An influential exposition of this idea can be found in Diamandouros's theory of 'cultural dualism' in Greek society and politics. ${ }^{75}$ In this view, there are two political cultures in Greece, a modernising one and the 'underdog' one, where the latter is associated with virtually all pathological aspects of Greek society and politics (populism, corruption, clientelism, backwardness, etc.) that work as obstacles to modernisation. The modernisation project of Prime Minister Costas Simitis (i.e. 'Powerful Greece'), was supported along such lines, and Simitis himself made use of the scheme of the 'two Greeces', where one Greece is pro-western and progressive, while the other is populist and resists all attempts at modernisation and associated reforms. ${ }^{76}$ In fact the cultural dualism' thesis has recently made a return and has been re-assessed as a way of explaining the current Greek economic crisis along these lines. ${ }^{77}$ Similar schemes of a split culture in terms of good and bad have been mobilised in pro-austerity journalistic accounts. ${ }^{78}$

But this idea of Greece as the cradle of Western civilisation has been prominent in much of pro-austerity discourse, often expressed in terms of an intense anxiety - a reaction to a threatened loss of this self-image. Here, loss appears to be loss of the Western gaze that supports national sovereignty and pride, a loss we must at all costs prevent. In the words of Lucas Papademos, leader of the technocratic coalition government,

[w]e Greeks will not carelessly lose... [our] most treasured... acquisition, our position in Europe. [...]Greece, the cradle of ancient political Europe is [an] integral participant of this common path towards closer European integration. Greece is Europe and Europe is unthinkable without Greece. ${ }^{79}$

We speculate that this fantasmatic self-image is a powerful and potent one, underlying not just the melancholic pathway but also the pathway of ressentiment. Crucially, in the crisis period this self-image was mobilised to pre-empt the contestation of the austerity doctrine with reference to the figure of Europe. One of the most characteristic responses to the doubters of austerity involved tarnishing them with an anti-European brush, thereby blurring the boundary between pro-European and pro-austerity positions. This became very clear in the case of the 2015 referendum (introduced by the SYRIZA-led government) where the proausterity parties sought to present the choice in terms of staying or leaving the EU. But even in the period under our examination, the figure of Europe is presented in a charged fashion in the two high-circulation pro-austerity newspapers - in Kathimerini more than in Ta Neaoften in ironic tones that signal the immanent and imminent threat of reappearing orientalising and balkanising tendencies:

Maybe now that we messed up as Europeans [...] we could start preparing for our accession to the United Arab Emirates. ${ }^{80}$

[T] he dilemma we have to answer is whether we eventually want to be a modern and European state or an isolated Balkan country. ${ }^{81}$ 
What is interesting is that several themes in the anti-austerity discourse can be seen as attempts to disrupt the aforementioned narrative and related narratives of guilt and failure, often reflecting anthropological observations of the way individual Greek subjects react to them. ${ }^{82}$ No doubt some of the anti-austerity interventions show signs of ressentiment (Greece being betrayed by the West, the depiction of EU and German officials as Nazis, shame for belonging to a submissive nation, desire for isolationism). Others, however, appeared more reflexive and nuanced, showing that opposition to austerity can take the form of an attachment to Europe. Such responses could politicise and also pluralise accounts of both Greece and Europe. Attempts to discredit these alternative expressions potentially limited the spectrum of possible non-resentful responses to austerity.

What this hints at, however, is that certain conditions have to be met for a (mournful) detachment from such a potent self-images and identity to take place successfully; and in the absence of these conditions we can talk about 'blocked mourning, ${ }^{83}$ For example, we can say that there must at least be some form of public recognition of potential loss. Containment or denial of loss, rather than the symbolic construction and affirmation of the loss of a selfimage, is clearly not conducive to the mourning process.

Take the case of melancholia. As we saw earlier, the way nationalist fantasies were mobilised to sustain the austerity policy solution make the proper processing of loss virtually impossible, so that a basic precondition for mourning is absent. Instead, Greeks are said to have an urgent duty to accept austerity in order to prevent the loss of national continuity and historical identity; and so the failure to fulfil the demands of austerity is understood to be a failure to discharge one's patriotic duty. This prohibits the formation of a judgement of loss, since such a judgement of loss would necessarily involve acknowledging some form of discontinuity and the emergence of a potentially alternative trajectory.

Consider, for example, the attempts to reduce or manipulate images of suffering that emerged early on as part of this tendency to contain loss in the name of national pride. Such concealment stifles a crucial aspect of mourning (i.e., the public display of concrete losses), which prevents the emergence of bonds of solidarity and the expansion of collective identifications on the grounds of collective suffering. ${ }^{84}$ In this view, public mourning involves exposing vulnerability as a fundamental feature of the human condition, thus enabling the formation of a 'we' based on the realisation that all life is precarious and fragile.

Indeed, Makis Voridis, Nea Demokratia spokesman, asserted that it was media images depicting wretchedness that were responsible for creating a 'climate of depression' and for the rise of suicide rates, not the government's austerity programme. ${ }^{85}$ Although some criticized Voridis's claims, many media outlets expressed support for this position. When the Guardian picked as its 'picture of the day' the shot of an Athenian crowd accepting food provided by farmers, Babis Papadimitriou, director of Skai TV, fiercely criticised the choice of the British newspaper during the main news broadcast of his TV station: 'The Guardian has been deploying anti-Greek propaganda that serves their own political goals... [The producers] obviously chose to distribute fruit in such a poor neighbourhood in order to humiliate their country [...] ${ }^{86}$ Again, our claim is that the more such images are censored, the more difficult it becomes not only to contest the austerity agenda (insofar as such wretchedness and pauperisation is understood to be a product of such an agenda), but also to allow public expressions of loss to emerge and for a collective 'we' to organise itself around it. 
These efforts at prohibiting or censoring a publicly shared recognition of loss are rather extreme and certainly not always successful. But it is worth noting that the simple public recognition of loss is not of itself sufficient for the process of mourning to unfold either. An appropriate context must also be in place and actively sustained for mourning to take its course, and in the absence of such a context 'blocked mourning' is still a likely outcome. Since the proper processing of loss is co-extensive with our confrontation with the contingency of social existence (since our fantasy and identity are at stake), and since the 'grip' of ideology is linked to our fantasmatic investment in economic and nationalist narratives, we claim that the identification of the unmet conditions of mourning can contribute to the task of ideological critique.

For example, we could say that severe restrictions of space and time suppressed the emergence of a context that could foster a mourning process. Consider the familiar role of the 'emergency situation' in political life from 2010 onwards. As an illustration of how this type of restriction blocks mourning, Judith Butler quotes George Bush declaring, only 10 days after 9/11: 'We have finished grieving [...] now is time for resolute action to take the place of grief' ${ }^{87}$ In the case of the Greek crisis, much of the austerity reforms and policies from 2010 to 2014 were prescribed by the Troika, the pro-austerity governments, and the media, as 'shock doctrine' medicine, declaring that only the 'resolute' and 'immediate' implementation of the austerity/bail-out plan would work. Even parliamentary deliberation was seen as a dangerous delay that needs to be prevented for the country's own good:

The bill is urgent for reasons that are nationally existential.... [Otherwise] the country will not manage to stand on its feet - it will become bankrupt.... We are 'writing' the country's fate now.... Enough with the games! This is about the country's future! ${ }^{88}$

Emergency deadlines were introduced for virtually all parliamentary votes on the austerity/bail-out agreements, making impossible not only democratic deliberation, but even the simple reading of the agreements, often comprising more pages than one could possibly read in the allotted time. Former PASOK Minister Michalis Chrysochoidies publicly confessed that he voted for the Memorandum without reading it at all. Justifying his actions, he said 'it took place under conditions of panic in view of the [nightmare] scenario of cessation of payments that was haunting us. We had our back against the wall' ${ }^{89}$ MPs were put under severe pressure from their parties to toe the line on pain of expulsion, with critics painted as irresponsible actors wilfully putting the country at risk.

As recent academic work has argued, the TINA (there-is-no-alternative) dogma has been one of the most widely used strategies of the pro-austerity camp, ${ }^{90}$ and much of the press has played a crucial role in reproducing this. ${ }^{91}$ In fact, out of the five newspapers we examined, the two with the highest circulation by far - Ta Nea and Kathimerini - expressed support for the proposed austerity measures, often arguing that even the mere contemplation of alternatives would result in a national disaster. Attempts to delegitimise the economic strategies of the Left (particularly SYRIZA) by presenting them as harbingers of 'collective suicide' are a clear case in point. ${ }^{92}$

Since the media comprise important agents that can affect the function of the public sphere, we can understand that, under such conditions, strong media business actors can play a crucial role in shaping our understanding of the crisis, promoting specific ways of framing and disregarding alternatives. Such a context, characterised by pressures and severe imbalances regarding the public visibility of different accounts and visions, means that the 
spatial and temporal conditions for mourning remained unmet. This is the case when grassroots collective economic projects, including health initiatives, time banks, co-ops and worker-controlled factories - understood as alternative responses to the effects of austerity - rarely received media attention. ${ }^{93}$ No doubt this has to do with the intense pressures and the climate of emergency through which the austerity reforms were introduced in Greece. These pressures certainly derive — at least partly — from a (neoliberal) pro-austerity hegemony on a global level but also on a European level, certainly since $2008 .{ }^{94}$ But the political discourse articulated by pro-austerity Greek governments, and supported by the strongest mainstream media, also played an essential role in the spread of these pressures. Such pressures did not simply offer substantive support for the TINA doctrine but they also served to block the mourning process, thereby contributing to the polarisation and instability of the Greek political order over this period.

Looking at this more closely we can discern how the large established newspapers (but also television stations) played a role in obstructing the conditions of mourning, something that can be explained by the political economy of the media in Greece and beyond, including the traditional relations between media owners and the PASOK and New Democracy governments of the last decades. ${ }^{95}$ It is well-documented that media owners come from the strongest sectors of the Greek economy, such as construction and shipping, whose companies have, for many years, been competing for, and winning, big state contracts. ${ }^{96}$ Indeed, the relations between the media and the state have been described in terms of patronage and clientelism. In this view, traditional political parties adopt favourable policies towards the media and the businesses of their owners, receiving favourable reporting in exchange. ${ }^{97}$ Austerity made these practices less affordable, but some remained or were replaced with new protections of media monopolies. ${ }^{98}$ Overall, then, the critique of ideology in this case cannot avoid appealing to analyses of the political economy landscape in Greece, including the rather tight interdependence among the traditional political establishment and the media.

\section{Conclusion: Mourning and Ideological Critique}

In completing the argument of our paper, the previous section focussed on the conditions that have made mourning difficult, thereby helping to tighten the ideological grip of the nationalist narrative underpinning the austerity and anti-austerity responses to the crisis. Ultimately the nationalist narratives thematise potent fantasies presenting visions about past glories and threats to that self-image, at least as it appears through the gaze of the West. Usually, the horrific aspects of these fantasies depict scenarios that threaten to undermine our attachment to these visions which then appear to need urgent and resolute defence. Repeated iteration and reinforcement of such fantasmatic scenarios militate against a more reflexive assessment and renegotiation taking root, especially as regards the links between Greece, Europe, and a neoliberalising austerity. From the point of view of ideological critique ('crossing the fantasy'), the task would then involve identifying and meeting the conditions of mourning. This would entail opening up a space for collective judgements about loss to take place in a context of relative openness (as opposed to a threatening and dismissive atmosphere in emergency situations), enabling the fantasmatic contours of the implicit guarantors to be revealed through a process of construction and transformation.

Insofar as these discursive and political-economic conditions remain unmet, however, they help account for the extreme polarisation and volatility of the Greek political order since 2010. As we saw the austerity/anti-austerity debate very quickly became a polarised dispute over who was a true patriot, affecting the content and tenor of engagement across the political 
spectrum, raising the stakes of the debate. The totalising character of the nationalist narrative was therefore a recipe for violent oscillations between pro and anti-establishment parties. We have suggested that the rigid polarisation was in part the product of the conditions of mourning remaining unmet. But of course the conditions of possibility of this polarised and volatile state of affairs furnish ideas about how things could proceed differently.

Our theoretical argument has been that ideology can be understood in terms of whether and how we confront loss or dislocation - of an object, a self-image, an ideal, an identity, etc. The 'grip' of an ideology is thus a product of efforts to contain, rather than register and confront, loss; and this 'blocked mourning' can be expressed in a number of symptomatic ways, such as melancholia and ressentiment. From this point of view, a critique of ideology would aim to 'unblock mourning', thereby focussing our attention on the conditions under which mourning can take place.

Key conditions of mourning involve enacting a publicly shared recognition of loss and ensuring there is an appropriate context within which to process this loss ethically and creatively, but these were compromised in the Greek case on account of the manner and style of the dominant response to the crisis performed and promoted by the government and the mainstream media (but not just by them). Registering and processing loss is ethically demanding because it entails affirming vulnerability and contingency and confronting anxiety in a context that valorizes a more muscular and decisive ethos. But it is demanding also because it entails engaging in a process of identifying and constructing fantasies that have made this particular configuration of loss possible, and thus potentially also re-articulating them in a different way. This process of re-articulation presupposes a different, less-invested, relation to fantasy and its ideals. It also entails finding a new language with which to respond to the crisis and to express identities in a way that avoids reinstating ossified self-images and ideals. Part of this process would involve extending an open invitation to a wide range of groups to engage collectively and deliberatively in forging a new way forward, both politically and culturally. The polarisation - expressed in nationalist and resentful terms drew attention away from certain critical and innovative practices that could foster mourning, usually operating at a grassroots level. ${ }^{99}$ Mourning conditions thus overlap with counterhegemonic conditions, since making such voices more accessible would involve putting into question norms of a governance network that sustain and protect a powerful nexus of vested interests at the intersection of the media field, economic regime, and political establishment. 


\section{Notes and References}

${ }^{1}$ Earlier versions of this paper were presented at the conference 'Psychoanalysis and Politics', Helsinki, 15-17 March 2013; the workshop 'Psychoanalysis as Theory and Method in the Arts', University of East Anglia, 10 May 2013; and the conference 'Psychoanalysis, Culture and Society', Middlesex University, 15 June 2013. For very helpful advice and feedback we thank Alan Finlayson, Leonidas Karakatsanis, Christos Pallas, and the anonymous assessors of JPI.

${ }^{2}$ A. Gramsci, Selections from the Prison Notebooks of Antonio Gramsci (London: Lawrence \& Wishart, 1971), p. 184.

${ }^{3}$ Gramsci, ibid., p. 210

${ }^{4}$ We qualify the crisis as an 'economic' crisis since this keeps open - but also registers - a whole 'politics of naming' associated with such qualifications. For example, some feel that qualifying the crisis as a sovereign debt crisis is already to erase broader structural and/or neoliberal features that ought to be considered central to any characterization of the crisis (M. Blyth, Austerity: the History of a Dangerous Idea (New York: Oxford University Press, 2013)).

${ }^{5}$ E. Dinas and L. Rori, 'The 2012 Greek Parliamentary Elections: Fear and Loathing in the Polls', West European Politics, 36(1) (2013), pp. 270-282.

${ }^{6}$ M. Prentoulis and L. Thomassen, 'Political Theory in the Square: Protest, Representation and Subjectification', Contemporary Political Theory, 12(3) (2013), pp. 166-184; D. Theodossopoulos, 'Infuriated with the Infuriated? Blaming Tactics and Discontent about the Greek Financial Crisis', Current Anthropology, 54(2) (2013), pp. 200221; M. Tsilimpounidi, 'Athens 2012', City, 16(5) (2012), pp. 546-556.

${ }^{7}$ Y. Stavrakakis and G. Katsambekis, 'Left-wing Populism in the European Periphery: the Case of SYRIZA', Journal of Political Ideologies, 19(2) (2014), pp. 119-142.

${ }^{8}$ R. Gerodimos and G. Karyotis, 'Austerity Politics and Crisis Governance: Lessons from Greece ' in R. Gerodimos and G. Karyotis (Eds) The Politics of Extreme Austerity: Greece in the Eurozone crisis (Basingstoke: Palgrave Macmillan, 2015), pp. 259-271.

${ }^{9}$ S. Boukala, 'Waiting for Democracy: Political Crisis and the Discursive (Re)invention of the 'National Enemy' in Times of "Grecovery”, Discourse \& Society, 25(4) (2014), pp. 483-499; Z. Lialiouti and G. Bithymitris, 'Implications of the Greek Crisis: Nationalism, Enemy Stereotypes, and the European Union' in B. M. Stefanova, (ed.) The European Union beyond the Crisis: Evolving Governance, Contested Policies, and Disenchanted Publics (London: Lexington Books, 2015), pp. 249-267.

${ }^{10}$ S. Zartaloudis, 'Greece and the Recent Financial Crisis: Meltdown or Configuration?' in F. Panizza and G. Philip (Eds) Moments of Truth: The Politics of Financial Crises in Comparative Perspective (London: Routledge, 2014), pp. 158-176; T. S. Pappas, Populism and Crisis Politics in Greece (London: Palgrave Macmillan, 2014), p. 104.

${ }^{11}$ See, for example, Y. Stavrakakis, Lacan and the Political, (London: Routledge, 1999); Y. Stavrakakis, The Lacanian Left: Psychoanalysis, Theory, Politics (Edinburgh: Edinburgh University Press, 2007).

${ }^{12}$ Democratic Left (DIMAR) can be seen as an example of the reverse: they supported the structural reforms introduced by the memorandum but opposed those parts introducing cuts of an austerity type.

${ }^{13}$ G. Daly, 'Ideology and its Paradoxes: Dimensions of Fantasy and Enjoyment', Journal of Political Ideologies, 4(2) (1999), pp. 219-238; J. Glynos, 'The Grip of Ideology: A Lacanian Approach to the Theory of Ideology', Journal of Political Ideologies, 6(2) (2001), pp. 191-214; J. Glynos, 'Ideological Fantasy at Work', Journal of Political Ideologies, 13(3) (2008), pp. 275-296; S. Žižek, 'Invisible ideology: Political Violence Between Fiction and Fantasy', Journal of Political Ideologies, 1(1) (1996), pp. 15-32.

${ }^{14}$ W.-Y. Chang and J. Glynos, 'Ideology and Politics in the Popular Press: the Case of the 2009 UK MPs' Scandal' in L. Dahlberg and S. Phelan (Eds) Discourse Theory and Critical Media Politics (Basingstoke: Palgrave Macmillan, 2011), pp. 106-127.

${ }_{15}^{15}$ Glynos, 'Ideological Fantasy at Work', op. cit., Ref. 13, pp. 276-277.

${ }^{16}$ Glynos, ibid., p. 276.

${ }^{17}$ Theodossopoulos, ibid.; D. Theodossopoulos, 'On De-Pathologizing Resistance', History and Anthropology, 25(4) (2014), pp. 415-430.

${ }^{18}$ G. Tzogopoulos, The Greek Crisis in the Media: Stereotyping in the International Press (Farnham: Ashgate, 2013).

${ }^{19}$ P. Tsoukala, 'Narratives of the European Crisis and the Future of (Social) Europe', Texas International Law Journal, 48(2) (2013), pp. 241-266.

${ }^{20}$ Y. Mylonas, 'Media and the Economic Crisis of the EU: The 'Culturalization' of a Systemic Crisis and BildZeitung's Framing of Greece', TripleC, 10(2) (2012), pp. 646-671.

21 J. Glynos, 'Death, Fantasy, and the Ethics of Mourning', in N. Carpentier and L. Van Brussel (Eds) The Social Construction of Death: Interdisciplinary Perspectives (London: Palgrave, 2014), pp. 137-160; C. Lapping, 'Melancholia', in her Psychoanalysis in Social Research (London: Routledge, 2011), pp. 14-41. 
${ }^{22}$ C. Özselçuk, 'Mourning, Melancholy, and the Politics of Class Transformation', Rethinking Marxism, 18(2) (2006), pp. 225-240.

${ }^{23} \mathrm{We}$ consider the votes on these 'multi-bills' to be important moments as regards the austerity agenda, because they were the means by which the bailout agreement stipulations were implemented (including layoffs in the public sector). Meeting these stipulations was necessary for Greece to be granted access to subsequent loan instalments.

${ }^{24} \mathrm{http}$ ://www.primeminister.gov.gr/

${ }^{25}$ Zartaloudis, op. cit., Ref. 10; Pappas, op. cit., Ref. 10, p. 104.

${ }^{26}$ D. Halikiopoulou, K. Nanou, and S. Vasilopoulou, 'The Paradox of Nationalism: The Common Denominator of Radical Right and Radical Left Euroscepticism', European Journal of Political Research, 51(4) (2012), pp. 504-539.

${ }^{27}$ E. Kirtsoglou, D. M. Knight, \& D. Theodossopoulos, 'Forum: Anthropology and the Crisis in Greece', Suomen Antropologi: Journal of the Finnish Anthropological Society, 38(1) (2013), pp. 104-115.

${ }^{28}$ Boukala, op. cit., Ref. 9.

${ }^{29}$ Lialiouti and Bithymitris, op. cit., Ref. 9.

${ }^{30}$ N. Panourgia, Dangerous Citizens: The Greek Left and the Terror of the State (New York: Fordham University Press, 2009).

${ }^{31}$ S. Dellepiane-Avellaneda, S. and N. Hardiman (2014) 'The politics of Fiscal Effort in Spain and Ireland' in Gerodimos and Karyotis, op. cit., Ref. 8, pp. 198-221.

${ }^{32}$ A. Freire, M. Lisi, I. Andreadis, and J. M. Leite Viegas, 'Political Representation in Bailed-out Southern Europe: Greece and Portugal Compared', South European Society and Politics, 19(4) (2014), 413-433.

${ }^{33}$ G. Papandreou, 'G. Papandreou's full statement', 24 April 2010, available at http://goo.gl/1ksOlv8 *.

${ }^{34}$ Nea Demokratia, 'The Strength of a Nation' (2012), available at https://goo.gl/Zbikfs *.

${ }^{35}$ Nea Demokratia, 'Antonis Samaras: Give me the Strength of a Nation' (2012), available at https://goo.gl/BzHgJv*.

36 'Tsipras: Greece or Merkel', Eleftherotypia, 22 April 2014, available at http://goo.gl/shRoHq *.

${ }^{37}$ Gramsci, op. cit., Ref. 2, p. 276.

${ }^{38}$ Y. Stavrakakis 'Dispatches from the Greek Lab: Metaphors, Strategies and Debt in the European Crisis', Psychoanalysis, Culture, and Society, 18(3) (2013), pp. 313-324 at p. 315. This mode is often reinforced by potent metaphors: austerity is presented as a bitter but necessary medicine to cure the moral disease or as an educational punishment that would straighten the child's immature behaviour (Y. Stavrakakis, 'Debt Society: Psychosocial Aspects of the (Greek) Crisis' in K. Kenny and M. Fotaki (Eds) The Psychosocial and Organization Studies: Affect at Work (Basingstoke: Palgrave Macmillan, 2014), pp. 33-59. For a related analysis of the role of debt as a mechanism of power and control in contemporary neoliberalism, see R. P. Klimecki, 'Reflections on the Greek Sovereign Debt Crisis and the Condition of the Indebted Man', in H. Schmid, H. and K. Stafylakis (Eds) The Other Designs: Historical Authenticity As Artistic Project (Norderstedt: BOD, 2014), pp. 19-25.

39 'Th. Pangalos: We all gorged on the money together', Eleftherotypia, 21 September 2010, available at http://goo.gl/z8pfsg *.

${ }^{40}$ G. Papandreou, 'Our fatherland demands from us that we move beyond ourselves', 12 February 2012 , available at: http://goo.gl/j8kPSZ *.

${ }^{41}$ G. Karyotis and W. Rüdig, 'Protest Participation, Electoral Choices and Public Attitudes towards Austerity in Greece' in Gerodimos and Karyotis, op. cit., Ref. 8, pp. 123-141.

42 A. Papahelas, 'The gene of self-destruction', Kathimerini, 27 May 2012 *.

${ }^{43}$ D. Kourtovik, 'Europeans or pro-European?', Ta Nea, 02 June 2012, available at http://goo.gl/kkC1Y5 *.

${ }^{44}$ L. Papademos, 'Prime Minister Lucas Papademos's Parliament speech about the 2012 budget', 6 December

2011, available at http://www.primeminister.gov.gr/2011/12/06/7127, accessed on 1 October 2012 *.

${ }^{45}$ N. Sevastakis 'Contemporary "Antipopulism": From Political Pathology to Cultural Evil' in N. Sevastakis and Y. Stavrakakis Populism, Anti-populism, and Crisis (Athens: Nefeli, 2012), pp. 9-41 at p. 21 *.

${ }^{46}$ L. Papademos, 'Prime Minister Lucas Papademos's message', 10 February 2012, available at www.primeminister.gov.gr/2012/02/11/7453, accessed on 2 October $2012 *$.

${ }^{47}$ Papademos, op. cit., Ref. 44.

${ }^{48}$ S. Žižek, Tarrying with the Negative: Kant, Hegel, and the Critique of Ideology (Durham: Duke University Press, 1993), pp. 201-203.

${ }^{49}$ F. Nietzsche, On the Genealogy of Morals / Ecce Homo (New York: Vintage, 1989), p. 127.

${ }^{50}$ Connolly in M. Wenman, Agonistic Democracy: Constituent Power in the Era of Globalisation, (Cambridge: Cambridge University Press, 2013), p. 121.

${ }^{51}$ W. E. Connolly, 'A world of becoming' in A. Finlayson (Ed) Democracy and Pluralism: The Political

Thought of William E. Connolly (London: Routledge, 2012), p. 226. 
${ }_{53}^{52}$ M. Ure 'Resentment/Ressentiment', Constellations, 22(4) (2015), pp. 599-613 at p. 608.

${ }^{53}$ D. Theodossopoulos, 'The Ambivalence of Anti-Austerity Indignation in Greece: Resistance, Hegemony and Complicity', History and Anthropology, 25(4) (2014), pp. 488-506.

${ }^{54}$ Z. Lialiouti and G. Bithymitris, "“The Nazis Strike Again": The Concept of "The German Enemy”, Party Strategies, and Mass Perceptions through the Prism of the Greek Economic Crisis' in C. Karner and B. Mertens (Eds) The Use and Abuse of Memory: Interpreting World War II in Contemporary European Politics (New Brunswick: Transaction Publishers, 2013), pp. 155-171.

55 'Tsipras: those who govern us are not so Greek, after all', Ta Nea, 20 February 2012, available at http://goo.gl/x5LE1s *.

${ }^{56}$ A. Tsipras, 'Speech of Alexis Tsipras, president of SYRIZA/EKM, at the central pre-election rally in Athens', 14 June 2012, available at http://goo.gl/nX9uwh *.

${ }^{57}$ Cartoons in Sunday Avgi, 12 February 2012.

${ }^{58}$ A. Samaras, 'Speech of Prime Minister Antonis Samaras at Nea Demokratia's preconvention', 9 June 2013, available at: http://www.primeminister.gov.gr/2013/06/09/12207 *.

59 'Loverdos: 'The primary cause of bureaucracy is the Constitution', Eleftherotypia, 7 September 2011., available at http://goo.gl/bsqJPs *.

${ }^{60}$ A. Athanasiou, 'Precarious Intensities: Gendered Bodies in the Streets and Squares of Greece', Signs, 40(1) (2014), pp. 1-9 at p. 7.

${ }^{61}$ Y. Schiby, 'E. Venizelos and the Jews', To Vima, 16 October 2012, available at http://goo.gl/G8ICvm *.

${ }^{62} \mathrm{~L}$. Keza, 'We the foreigners', To Vima, available at http://goo.gl/zC0jRv *.

${ }^{63}$ 'Samaras: 'we have as many illegal immigrants as we have unemployed - enough is enough", Ta Nea, 21 October 2013, available at http://goo.gl/xnJpfa *.

${ }^{64}$ 'N. Dendias on migration: we are confronting a new "Dorian Invasion"', To Vima, 6 August 2012, available at http://goo.gl/kReWzp *.

${ }^{65}$ A. A. Ellinas, 'The Rise of Golden Dawn: The New Face of the Far Right in Greece', South European Society and Politics, 18(4) (2013), pp. 543-565.

${ }^{66}$ Lialiouti and Bithymitris, op. cit., Ref. 9, pp. 260-264

${ }^{67}$ A. Tsipras, 'Speech of prime minister A. Tsipras during the discussion regarding the referendum of the $5^{\text {th }}$ of July', 28 June 2015, available at http://goo.gl/ew2sPi *. 'Dignity' was uttered 21 times in Tsipras's 42 minute speech.

${ }^{68}$ S. Freud, 'Mourning and Melancholia' in J. Strachey (Ed) The Complete Psychological works of Sigmund Freud: Vol. 14 (London: Hogarth Press and the Institute of Psychoanalysis, 1957), pp. 237-260 at p. 245.

${ }^{69}$ P. Lather, Getting Lost: Feminist Efforts toward a Double(d) Science, (New York: State University of New York Press, 2012), p. 107.

${ }^{70} \mathrm{M}$. Spyridakis, The Liminal Worker: an Ethnography of Work, Unemployment and Precariousness in Contemporary Greece (Farnham: Ashgate, 2013), p. 1.

${ }^{71}$ Glynos, op. cit., Ref. 21.

${ }^{72}$ S. Gourgouris, Dream Nation: Enlightenment, Colonization, and the Institution of Modern Greece (Stanford: Stanford University Press, 1996).

${ }^{73}$ Gourgouris, ibid., p. 6.

${ }^{74}$ K. Featherstone, (2006) Politics and Policy in Greece: The Challenge of Modernisation (London: Routledge, 2006), p. 251

${ }^{75}$ N. P. Diamandouros, 'Cultural Dualism and Political Change in Post-authoritarian Greece', working paper 50 (Madrid: Instituto Juan March de Estudios e Investigaciones, 1994).

${ }^{76}$ For a critical analysis of the 'cultural dualism' thesis, see Y. Stavrakakis, 'Religious Populism and Political Culture: The Greek Case', South European Society and Politics, 7(3) (2002), pp. 29-52.. For a related anthropological account, see M. Herzfeld, Anthropology Through the Looking-Glass: Critical Ethnography in the Margins of Europe (Cambridge: Cambridge University Press, 1989)..

${ }^{77}$ A. Triandafyllidou, R. Gropas, and H. Kouki, The Greek Crisis and European Modernity (Basingstoke: Palgrave Macmillan, 2013).

${ }^{78}$ See, for example the aforementioned quote from Kathimerini, blaming a particular Greek 'self-destructive gene' for the resistance to austerity.

${ }_{79}^{70}$ Papademos, op. cit., Ref. 44, emphasis added

${ }^{80}$ St. Kasimatis, 'The Left is a bit touchy', Kathimerini, 2 May 2010, available at http://goo.gl/QoiR8a *.

${ }^{81}$ S. Kedikoglou, 'Escape - to the future or to the past', Ta Nea, 29 June 2011, available at http://goo.gl/pf3jjl *.

${ }^{82}$ K. Kalantzis, “"Fak Germani”: Materialities of Nationhood and Transgression in the Greek Crisis', Comparative Studies in Society and History, 57(04) (2015), pp. 1037-1069. 
${ }^{83}$ Glynos, op. cit., Ref. 21; J. Glynos, K. West, B. Hagger, and R. Shaw, 'Narrative, Fantasy, and Mourning: A Critical Exploration of Life \& Loss in Assisted Living Environments' in K. Kenny and M. Fotaki (Eds) The Psychosocial and Organization Studies: Affect at Work (London: Palgrave Macmillan, 2014), pp. 185-214.

${ }^{84}$ J. Butler, Precarious Life: The Powers of Mourning and Violence (London: Verso, 2006).

85 'Voridis against the Left but also the media(!)', TVXS, 11 March 2013, available at http://goo.gl/0HSytQ *.

86 'Skai with Nikos Evaggelatos', Skai, 6 February 2013, available at http://goo.gl/fbLPiY *.

${ }^{87}$ George Bush in Butler, op. cit., Ref. 84, p. 29, emphasis added.

${ }^{88}$ E. Venizelos, 'Interventions of the Government's Vice President and Minister of Finance Mr Evangelos Venizelos at the Parliamentary Standing Committee on Economic Affairs', 11 February 2012, available at http://goo.gl/dfnO2u *.

${ }^{89}$ St. Kandias, 'M. Chrysohoidis: 'I didn't read the memorandum', Skai, 24 February 2012, available at http://goo.gl/JbOfvv *.

${ }^{90}$ Gerodimos and Karyotis, op. cit., Ref. 8.

${ }^{91}$ Y. Mylonas, 'Crisis, Austerity, and Opposition in Mainstream Media Discourses of Greece, Critical

Discourse Studies, 11(3) (2014), pp. 305-321; Tzogopoulos, op. cit., Ref. 18. For an analysis of the legitimation mechanisms deployed in the most widely circulated Greek newspapers, see V. Doudaki, 'Legitimation Mechanisms in the Bailout Discourse', Javnost - The Public, 22(1), pp. 1-17. Pro-austerity media discourse would often present left-wing and far right responses to austerity as equally dangerous, in an attempt to delegitimise alternatives to austerity tout court (see P. Hatzopoulos and K. Patelis, 'The Comrade is Violent: Liberal Discourses of Violence in Anti-austerity Greece', Theory \& Event, 16(1) (2013), available at http://muse.jhu.edu/journals/theory and event/v016/16.1.hatzopoulos.html).

92 'In the uncharted seas of stupidity', Kathimerini, 30 June 2013, available at http://goo.gl/RK2sA4 *.

${ }^{93}$ Something similar can be said of the rise of the popular movement of 'Aganaktismenoi', a surge that lasted for several months, roughly resembling other expressions of the 'Occupy' movements. Importantly, much of the pro-austerity press was silent on the nuances of the social demands it incorporated, preferring instead to 'exoticize' the movement, presenting it as an intriguing spectacle.

${ }^{94}$ M. A. Centeno and J. N. Cohen, 'The Arc of Neoliberalism', Annual Review of Sociology, 38(1) (2012), pp. 317-340; F. De Ville and J. Orbie, 'The European Commission's Neoliberal Trade Discourse Since the Crisis: Legitimizing Continuity through Subtle Discursive Change', The British Journal of Politics \& International Relations, 16(1) (2014), pp. 149-167; P. Nousios, H. Overbeek, and A. Tsolakis (Eds) Globalisation and European Integration: Critical Approaches to Regional Order and International Relations (Abingdon: Routledge, 2012); I. Schmidt, 'Unmaking Neoliberal Europe: Capitalist Crisis and the Search for Alternatives', Perspectives on Global Development and Technology, 12(1-2) (2013), pp. 41-62. On the relation between neoliberalism, politics and the media more generally, see S. Phelan Neoliberalism, Media and the Political (London: Palgrave MacMillan, 2015).

${ }^{95}$ P. Iosifidis and D. Boucas (2015) 'Media Policy and Independent Journalism in Greece', report, (London and Barcelona: Open Society Foundations, 2015).

${ }^{96}$ A. Michailidou and H.-J. Trenz, 'Eurocrisis and the Media: Preserving or Undermining Democracy?', ARENA Working Paper, 14(10) (2014), pp. 1-22; N. Leandros, 'Media Concentration and Systemic Failures in Greece', International Journal of Communication, 4 (2010), pp. 886-905. Shipping firms enjoy tax exemptions that are protected by the Greek constitution.

${ }^{97}$ S. Papathanassopoulos, 'Greece: Press Subsidies in Turmoil' in P. Murschetz (Ed) State Aid for Newspapers (Berlin-Heidelberg: Springer, 2013), pp. 237-251 at p. 238; 248.

${ }^{98}$ Iosifidis and Boucas, op. cit., Ref. 95, pp. 22-24.

${ }^{99}$ Th. Rakopoulos, 'Responding to the Crisis: Food Co-operatives and the Solidarity Economy in Greece', Anthropology Southern Africa, 36(3-4) (2013), pp. 102-107; D. Margomenou and F. Papavasiliou, 'Times of Crisis and Seeds of New Intimacies on a North Aegean Island: Activism, Alternative Exchange Networks, and Re-Imagined Communities', Studies in Ethnicity and Nationalism, 13(3) (2013), pp. 523-529.

* Titles are translations from the original Greek source. 